\title{
Shifts in microbial stoichiometry upon nutrient addition do not capture growth-limiting nutrients for soil microorganisms in two subtropical soils
}

\author{
Christoph Rosinger · Katharina M. Keiblinger ${ }^{\circledR} \cdot$ \\ Johannes Rousk • Hans Sandén
}

Received: 30 July 2021 / Accepted: 15 February 2022 / Published online: 26 February 2022

(C) The Author(s) 2022

\begin{abstract}
Microbial stoichiometry has become a key aspect in ecological research as shifts in microbial C:N, C:P and N:P ratios upon nutrient addition are presumed to give insight into relative nutrient limitations for soil microorganisms-with far-reaching implications for biogeochemical processes. However, this expectation has never been tested against direct methods of microbial growth responses to nutrient addition. We therefore manipulated a subtropical grassland and forest soil with multifactorial $\mathrm{C}-, \mathrm{N}$ - and $\mathrm{P}$-additions during 30 days to induce changes in limiting resources and evaluated the resulting soil microbial growth rates, microbial
\end{abstract}

Responsible Editor: Melanie A. Mayes.

C. Rosinger $\cdot$ K. M. Keiblinger $(\triangle)$

Institute of Soil Research, Department of Forest- and Soil

Sciences, University of Natural Resources and Life

Sciences Vienna (BOKU), Vienna, Austria

e-mail: katharina.keiblinger@boku.ac.at

C. Rosinger

Institute of Agronomy, Department of Crop Sciences,

University of Natural Resources and Life Sciences Vienna

(BOKU), Tulln, Austria

J. Rousk

Section of Microbial Ecology - MEMEG, Department of Biology, Lund University, Lund, Sweden

H. Sandén

Institute of Forest Ecology, Department of Forest- and Soil

Sciences, University of Natural Resources and Life

Sciences Vienna (BOKU), Vienna, Austria biomass stoichiometry, potential enzyme activities and microbial community composition. Our results show that microbial stoichiometric shifts upon nutrient addition ambiguously predict growth-limiting nutrients for soil microbes. For example, P- and NPaddition to the grassland soil significantly shifted the microbial N:P ratio, which suggests increased N- relative to P-limitation. Microbial growth responses however indicated that soil microbes remained $\mathrm{C}$ limited. The same applies for the forest soil, where P-, CN-, NP- and CNP-additions shifted the microbial N:P ratio, yet microbial growth remained $\mathrm{C}$ limited. This indicates that microorganisms can immobilize $\mathrm{N}$ and $\mathrm{P}$ for storage when $\mathrm{C}$ is the main limiting nutrient, and that intracellular storage of $\mathrm{N}$ and $\mathrm{P}$ is responsible for the observed shifts in microbial stoichiometry. Moreover, our data imply that shifts in microbial C:N ratios do not necessarily indicate shifts in microbial community composition and suggest that soil microorganisms-when subject to resource pulses-are stoichiometrically quite plastic.

Keywords Limiting factors for growth · Microbial biomass $\cdot$ Microbial growth $\cdot$ Microbial stoichiometry $\cdot$ Nutrient limitation
Abbreviations
C Carbon
MB-C Soil microbial biomass carbon
MB-N Soil microbial biomass nitrogen
MB-P Soil microbial biomass phosphorus 


\section{N Nitrogen \\ P Phosphorus}

\section{Introduction}

Microbial stoichiometry has been a focal point in research in recent years. It is believed that stoichiometric imbalances between microbial communities and their resources have major implications for biogeochemical processes, particularly in soil systems (Manzoni et al. 2010; Mooshammer et al. 2014). Global-scale analyses found soil microbial biomass $\mathrm{C}: \mathrm{N}: \mathrm{P}$ composition to be rather constrained around 60:7:1 (Cleveland and Liptzin 2007) or 42:6:1 (Xu et al. 2013), thus indicating a relatively strict homeostasis of soil microorganisms (Sterner and Elser 2002). As a result, changes in microbial biomass $\mathrm{C}, \mathrm{N}$ and $\mathrm{P}$ contents (Allen and Schlesinger 2004; Turner and Wright 2014; Camenzind et al. 2018) and hence shifts in microbial stoichiometry upon nutrient addition are expected to indicate nutrient limitation for microbial growth (Cleveland and Liptzin 2007). For example, Griffiths et al. (2012) could show that microbial biomass $\mathrm{C}: \mathrm{P}$ ratios were subject to shifts in a long-term $\mathrm{P}$ fertilization experiment, as microbial biomass $\mathrm{C}: \mathrm{P}$ ratios decreased with $\mathrm{P}$ fertilization relative to an unfertilized control; supported by substrate-induced respiration measurements, they concluded that microbial biomass $\mathrm{C}: \mathrm{P}$ shifts indicate $\mathrm{P}$ limitation of soil microorganisms. To our knowledge however, the use of microbial stoichiometry (and shifts therein) to infer nutrient limitation has never been tested against direct methods of microbial growth responses to nutrient additions. Recently, studies have emerged that challenge the idea of strict microbial homeostasis (e.g. Fanin et al. 2013; Chen et al. 2019a). For example, soil microbes were found to sequester high rates of $\mathrm{N}$ and $\mathrm{P}$ into their microbial biomass during leaf litter decomposition, which subsequently resulted in rather plastic microbial C:P and $\mathrm{N}: \mathrm{P}$ ratios of the decomposer community (Fanin et al. 2013). Because the importance of microbial stoichiometry as a regulator of soil $\mathrm{C}$ and $\mathrm{N}$ fluxes has been more and more recognized in recent years (Buchkowski et al. 2015, 2019), it is crucial to understand and evaluate the predictive power of microbial stoichiometry. Therefore, the aim of this current study is to evaluate whether shifts in microbial stoichiometry upon nutrient addition can determine limiting nutrients (i.e. $\mathrm{C}, \mathrm{N}$ and $\mathrm{P}$ ) for soil microorganisms. As this is a sequel study of Rosinger et al. (2019), we make partial use of data from this preceding study, where we incubated a grassland and a forest soil from the Afromontane subtropical highlands with multi-factorial $\mathrm{C}, \mathrm{N}$ and $\mathrm{P}$ additions for four weeks and investigated fungal and bacterial growth responses (Bååth et al. 2001; Rousk and Bååth 2007), potential activities of $\mathrm{C}$ - $(\beta$-glucosidase $), \mathrm{N}$-(leucine amino-peptidase, $\quad \mathrm{N}$-acetyl- $\beta$-D-glucosaminidase) and P-(phosphatase) indicator enzymes (Sinsabaugh and Follstad Shah 2012) and PLFA composition for microbial community analysis (Frostegård et al. 1993; Cruz-Paredes et al. 2017). In this previous study, we investigated whether enzymatic stoichiometry can be used to infer growth-limiting nutrients for soil microorganisms. While enzymatic C:N, C:P and $\mathrm{N}: \mathrm{P}$ ratios indicated $\mathrm{P}$ and $\mathrm{CP}$ limitation in a grassland and forest soil, respectively, microbial growth responses clearly suggested a primary limitation by $\mathrm{C}$ in both land-use systems. We thus concluded that shifts in enzymatic stoichiometry upon nutrient addition do not reliably indicate growth-limiting nutrients.

On the same set of soil samples, we also measured soil microbial biomass $\mathrm{C}(\mathrm{MB}-\mathrm{C}),-\mathrm{N}(\mathrm{MB}-\mathrm{N})$ and $-\mathrm{P}$ (MB-P) using the widely acknowledged chloroform fumigation-extraction method (Voroney et al. 2008). Consequently, we report here the response of microbial stoichiometry upon nutrient addition and discuss the results in conjunction with microbial growth and community responses from the previously published data from Rosinger et al. (2019). This allows us to assess whether shifts in microbial stoichiometry upon nutrient addition can be used to infer limiting nutrients for soil microorganisms. Applying a specific definition of nutrient limitation to soil microorganisms is everything but straight-forward and often depends on the research question. We follow the wellestablished, Liebig-based approach of nutrient limitation and refer it to growth, as it is commonly used for primary producers (Elser et al. 2007). Thus, our main hypothesis is: Shifts in microbial biomass $\mathrm{C}: \mathrm{N}$, $\mathrm{C}: \mathrm{P}$ and $\mathrm{N}: \mathrm{P}$ ratios upon nutrient addition accurately indicate growth-limiting nutrients for soil microorganisms. In particular, we expect that the nutrient limiting microbial growth (e.g. N) should be scarce in the microbial biomass relative to all other nutrients (i.e. C and P). Therefore, the release of a particular 
nutrient limitation (e.g. N), as indicated by microbial growth responses, should lead to corresponding shifts in microbial biomass $\mathrm{C}: \mathrm{N}$ and $\mathrm{N}: \mathrm{P}$ ratios.

\section{Materials and methods}

Experimental setup

Two different soils from the Northern Ethiopian highlands were chosen for the experiment: $(i)$ a forest soil characterized as Cambisol ( $\mathrm{pH} 6.9 ; 13.2 \% \mathrm{C}$; $1.0 \% \mathrm{~N} ; 0.12 \% \mathrm{P} ; 2.5 \mathrm{mg} \mathrm{MB}-\mathrm{C}$ g dry soil ${ }^{-1}$ ) from an intact, old-growth forest system; and (ii) a soil from an adjacent grassland characterized as Andosol $(\mathrm{pH}$ 6.0; 3.6\% C; $0.3 \% \mathrm{~N} ; 0.06 \% \mathrm{P} ; 0.5 \mathrm{mg}$ MB-C g dry soil $^{-1}$ ). The forest soil is a $\mathrm{C}$-rich black soil, whereas the adjacent grassland soil is rather degraded and unfertile as a result of intensive grazing and strong erosion. Soil from 0 to $10 \mathrm{~cm}$ was taken in the end of the dry season of 2016, passed through a $2 \mathrm{~mm}$ sieve, transported to Austria in plastic bags and stored at $4{ }^{\circ} \mathrm{C}$. For more details about the sites and the soil sampling procedure see Assefa et al. (2017). All experiments conducted with these soils maintained three independent replicates $(n=3)$, which was also the independence used for all statistical analyses.

$\sim 40 \mathrm{~g}$ of soil were weighted in into sterilized $50 \mathrm{ml}$ plastic centrifugation tubes in triplicates. Tubes were covered with a mineral wool and pre-incubated in the dark at $22{ }^{\circ} \mathrm{C}$ for two weeks. Water content was set to reach optimal moisture at $50 \%$ of the water holding capacity, with deionized water. This level was controlled gravimetrically every three days and adjusted as needed.

After the pre-incubation, the soils were incubated for 30 days with semi-continuous additions of $\mathrm{C}, \mathrm{N}$ and $\mathrm{P}$ in a full factorial design (maintaining the three replicates). The chosen $\mathrm{C}: \mathrm{N}: \mathrm{P}$ nutrient ratio of the loadings was 10:1:1 by mass, resulting in total additions of $8 \mathrm{mg} \mathrm{C} \mathrm{g} \mathrm{dry} \mathrm{soil}{ }^{-1}$ and $0.8 \mathrm{mg} \mathrm{N}$ and $\mathrm{P} \mathrm{g}$ dry soil $^{-1}$, respectively. Although the soil $\mathrm{pH}$ was rather neutral, we chose high amounts of $\mathrm{P}$ deliberately in order to compensate for potential sorption of $\mathrm{P}$ to Al- and Fe-oxides. Wheat straw (C:N:P mass ratio of 450:10:1) was chosen as the carbon source. $\mathrm{N}$ and $\mathrm{P}$ were applied in the form of a $0.25 \mathrm{M} \mathrm{NH}_{4} \mathrm{NO}_{3}$ and a $0.1 \mathrm{M} \mathrm{K}_{2} \mathrm{HPO}_{4} / \mathrm{KH}_{2} \mathrm{PO}_{4}$ solution, respectively, adjusted to $\mathrm{pH} 6.0$ and 6.9 for the grassland and forest soil, respectively. Control samples received deionized water. The C-loading treatments (straw) were administered on days 0 and 15 , while the $\mathrm{N}$ - and P-loading treatments were added as solutions on days 0, 5, 10, 15, 20 and 25. During the incubation period, the water content was set at $50 \%$ of the water holding capacity, controlled every 3 days, and adjusted as needed. On day 30 , soils were stored at $4{ }^{\circ} \mathrm{C}$ until further examination, and aliquots of $1 \mathrm{~g}$ soil were frozen at $-20{ }^{\circ} \mathrm{C}$ for PLFA analyses. From now on, we refer to these nutrient addition treatments as 'long-term nutrient additions'.

Alongside the determination of $\mathrm{MB}-\mathrm{C},-\mathrm{N}$ and $-\mathrm{P}$, the soil samples were investigated for bacterial and fungal growth rates (Bååth et al. 2001; Rousk and Bååth 2007), respiration, potential enzymatic activities (Marx et al. 2001; German et al. 2011) and microbial community analysis (Frostegård et al. 1993; Cruz-Paredes et al. 2017). See Rosinger et al. (2019) for a detailed description on how these methods were used.

Soil samples following the long-term nutrient additions were subjected to another multifactorial C-, $\mathrm{N}$ - and $\mathrm{P}$-addition and investigated for responses in microbial growth and respiration, in order to determine limiting factors for growth. Briefly, soils were subdivided in $2 \mathrm{~g}$ aliquots, and $\mathrm{C}$ (as D-Glucose;

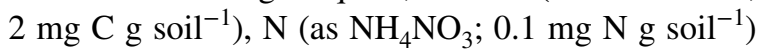
and $\mathrm{P}$ (as $\mathrm{KH}_{2} \mathrm{PO}_{4} / \mathrm{K}_{2} \mathrm{HPO}_{4} ; 0.1 \mathrm{mg} \mathrm{N} \mathrm{g} \mathrm{soil}{ }^{-1}$ ) solutions were added in a multifactorial design. Soils were incubated for $60 \mathrm{~h}$ at $22{ }^{\circ} \mathrm{C}$ before bacterial growth, fungal growth and respiration measurements. From now on, we refer to these treatments as 'shortterm nutrient additions'.

Microbial biomass $\mathrm{C}, \mathrm{N}$ and $\mathrm{P}$

MB-C and - $\mathrm{N}$ were determined by the fumigationextraction method (Vance et al. 1987; Witt et al. 2000; Voroney et al. 2008). Two sets of subsamples (5 g) were taken from fresh samples. One set was shaken in $25 \mathrm{ml}$ of $0.5 \mathrm{M} \mathrm{K}_{2} \mathrm{SO}_{4}$ for $1 \mathrm{~h}$, then centrifuged and filtered, and soil extracts were subsequently analysed for dissolved organic C (DOC) and total dissolved N (TDN) with a Shimadzu TOC-L analyzer (Shimadzu Corp., Kyoto, Japan). The other set of samples was fumigated with $40 \mathrm{ml}$ of ethanol-free chloroform for $24 \mathrm{~h}$. After fumigation, soil extractions and $\mathrm{C}$ and $\mathrm{N}$ measurements were performed as described above. Soil MB-C and 
$-\mathrm{N}$ were determined as the difference of fumigated and non-fumigated DOC and TDN, respectively. Microbial biomass $\mathrm{C}$ and $\mathrm{N}$ were corrected by extraction efficiency factors of 0.45 (Vance et al. 1987) and 0.54 (Brookes et al. 1985), respectively, and are expressed in $\mathrm{mg}$ and $\mu \mathrm{g} \mathrm{g}$ dry soil ${ }^{-1}$.

MB-P was determined according to Voroney et al. (2008). Briefly, fresh soil was extracted fumigated and unfumigated in a $1: 10 \mathrm{w} / \mathrm{v}$ ratio using $0.5 \mathrm{M} \mathrm{NaHCO}_{3}$ $\mathrm{pH}$ of 8.5 as extractant (Brookes et al. 1982). The $\mathrm{NaHCO}_{3}$ extracts as well as inorganic and organic (using phytate; to account for digestion efficiency) standards were digested with acid persulphate reagent mix in equal amounts (Rowland and Haygarth 1997). Digestion was conducted in $6 \mathrm{ml}$ glass vials in an autoclave at $120{ }^{\circ} \mathrm{C}$ for $1 \mathrm{~h}$. Fumigated and unfumigated, persulfate digested samples as well as standards were measured photometrically after phosphomolybdate blue reaction (Murphy and Riley 1962; PerkinElmer® 2300 EnSpire $^{\mathrm{TM}}$, USA). No correction factor was applied for calculation of microbial biomass P. Results are expressed in $\mu \mathrm{g}$ g dry soil ${ }^{-1}$.

\section{Statistical analysis}

Our data were normally distributed with homogenous variance. One-way ANOVA and post-hoc Tukey tests were used to determine significant treatment differences for $\mathrm{MB}-\mathrm{C},-\mathrm{N}$ and $-\mathrm{P}$ as well as for microbial $\mathrm{C}: \mathrm{N}, \mathrm{C}: \mathrm{P}$ and $\mathrm{N}: \mathrm{P}$ ratios. Moreover, a 3-way ANOVA was used to determine the effect of $\mathrm{C}, \mathrm{N}$ and $\mathrm{P}$ in the different treatments as well as their interactions. We also conducted categorical principal component analyses for both soil systems. The different nutrient treatments were used as categories, with potential enzyme activities (LAP, leucine amino-peptidase; NAG, N-acetyl-glucosaminidase; GLU, ß-glucosidase; PHO, phosphatase), microbial growth rates (bacterial and fungal growth), MB-C, $-\mathrm{N}$ and $-\mathrm{P}$, total PLFAs and respiration as explanatory variables. We refer to overall significant differences at the $\mathrm{p}<0.05$ level, with $* \mathrm{p}<0.05 ; * * \mathrm{p}<0.01$; and $* * * \mathrm{p}<0.001$. All statistical analyses were conducted in SPSS 26.

\section{Results}

Microbial biomass and stoichiometry responses to long-term nutrient additions

Overall, microbial biomass $\mathrm{C}: \mathrm{N}: \mathrm{P}$ ratios (on a weight base) of the grassland and forest control soils are 107:19:1 and 81:15:1, respectively.

In the grassland soil, MB-C contents were found to be significantly increased in all $\mathrm{C}$-treatments $(\mathrm{p}<0.05$; Fig. 1a). CP- and CNP-addition yielded significantly higher MB-C as compared to $\mathrm{CN}$-addition in both soils $(\mathrm{p}<0.05)$. Moreover, NP-addition led to significantly increased $\mathrm{MB}-\mathrm{C}$ as compared to the control $(p<0.05$; Fig. 1a). MB-N was significantly higher in all treatments that received $\mathrm{N}$ as compared to all others $(p<0.05$; Fig. 1b). Similarly, MB-P increased in the P-, NP- and CNP-treated grassland soils $(p<0.05$; Fig. $1 c)$, yet not in the CP-treatment. As a result, the microbial biomass $\mathrm{C}: \mathrm{N}$ ratio significantly decreased in all treatments that received $\mathrm{N}$ as compared to the control, and increased in the CP-treatment $(p<0.05$; Fig. 1d). Microbial C:P ratios in the $\mathrm{P}-, \mathrm{NP}-$ and CNP-treatments were significantly lower as compared to the control $(\mathrm{p}<0.05$; Fig. 1e), while microbial $\mathrm{N}: \mathrm{P}$ ratios in the $\mathrm{P}$ - and NP-treatment were significantly lower than the control samples ( $p<0.05$; Fig. 1f).

As for the forest soil, MB-C contents were also found to be significantly increased in all C-treatments ( $p<0.05$; Fig. 2a), with C-, CP- and CNPadditions yielding significantly higher $\mathrm{MB}-\mathrm{C}$ as compared to the $\mathrm{CN}$-addition $(\mathrm{p}<0.05)$. Only the C-treated soil (and marginally the CP-treated soil; $\mathrm{p}=0.057$ ) showed significantly higher MB-N contents as compared to the control ( $p<0.05$; Fig. $2 b)$, while MB-P was invariant across all treatments (Fig. 2c). The addition of $\mathrm{CN}$ led to a significantly increased microbial $\mathrm{C}: \mathrm{N}$ ratio as compared to all other treatments $(p<0.05$; Fig. 2d) (except for the CNP-treatment). The observed patterns in the response of the microbial $\mathrm{C}: \mathrm{P}$ and $\mathrm{N}: \mathrm{P}$ ratios to the nutrient additions (Fig. 2e,f) were similar, i.e., significant differences occurred solely between the P-, NP- and CNP-treated soil (where ratios decreased) and the $\mathrm{CN}$-treatment (where the ratio increased) $(\mathrm{p}<0.05)$. 

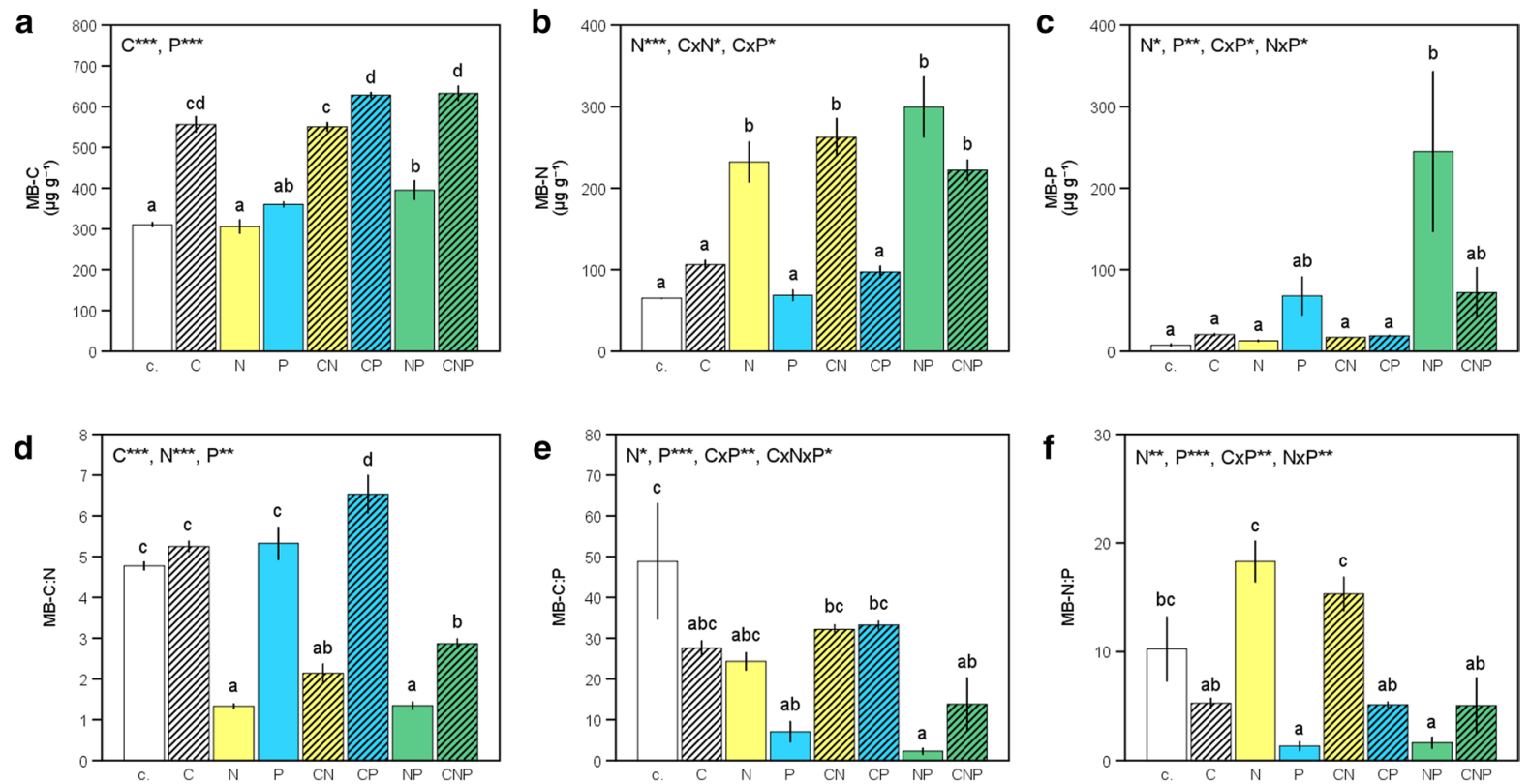

Fig. 1 Soil microbial biomass $\mathrm{C}, \mathrm{N}$ and $\mathrm{P}$ (a-c in $\mu \mathrm{g} g$ dry soil $^{-1}$ ) as well as microbial C:N, C:P and N:P ratios (d-f; on weight base) of the grassland soil following long-term multifactorial nutrient addition (c, control). Given is the mean $\pm \mathrm{SE}$ $(n=3)$, and different lowercase letters indicate significant dif-

PLFA composition responses to long-term nutrient additions

In the grassland, the addition of $\mathrm{C}, \mathrm{CN}$ and $\mathrm{CP}$ significantly increased the ratio of fungal to bacterial PLFAs $(p<0.05$; Supplementary Figure 1a). The ratio of grampositive to gramnegative bacteria significantly decreased with the addition of $\mathrm{C}$ and CP ( $p<0.05$; Supplementary Figure $1 c)$. In the forest soil, all C-treated soils showed a significantly increased fungi:bacteria ratio as compared to all non C-treated soils $(\mathrm{p}<0.05$; Supplementary Figure $1 \mathrm{~b})$. $\mathrm{N}$-addition significantly increased the ratio of grampositive to gramnegative bacteria as compared to the control, while CP- and CNP-addition decreased it $(p<0.05$; Supplementary Figure 1d). Detailed information on the PLFA composition can be found in Supplementary Table 1 and 2, and in Rosinger et al. (2019). ferences between treatments at the $\mathrm{p}<0.05$ level as revealed by one-way ANOVA and post-hoc Tukey tests. Significant treatment and interaction effects as revealed by 3-way ANOVA are displayed in the upper left corner, with $* \mathrm{p}<0.05$; $* \mathrm{p}<0.01$; $* * * \mathrm{p}<0.001$

Potential soil enzyme activity responses to long-term nutrient additions

GLU and LAP activities increased significantly in the $\mathrm{C}-$, $\mathrm{CN}$ - and CNP-treated grassland soils, while NAG activities only increased with $\mathrm{CN}$-addition $(\mathrm{p}<0.05$; Supplementary Table 3). PHO activities as well as the sum activity of all measured enzymes significantly increased in the $\mathrm{CN}$-treated soil and significantly decreased in the NP-treated soil $(\mathrm{p}<0.05)$.

In the forest soil, GLU activities only increased in the $\mathrm{CN}$-treated soil as compared to the control, while LAP activities only increased in the CP-treated soil ( $p<0.05$; Supplementary Table 4). All C-treated soils showed an increase in NAG activity $(\mathrm{p}<0.05)$, while PHO activity was invariant across all treatments $(p>0.05)$. The sum enzyme activity was found to be significantly increased only in the $\mathrm{CN}$-treated soil $(\mathrm{p}<0.05)$. 

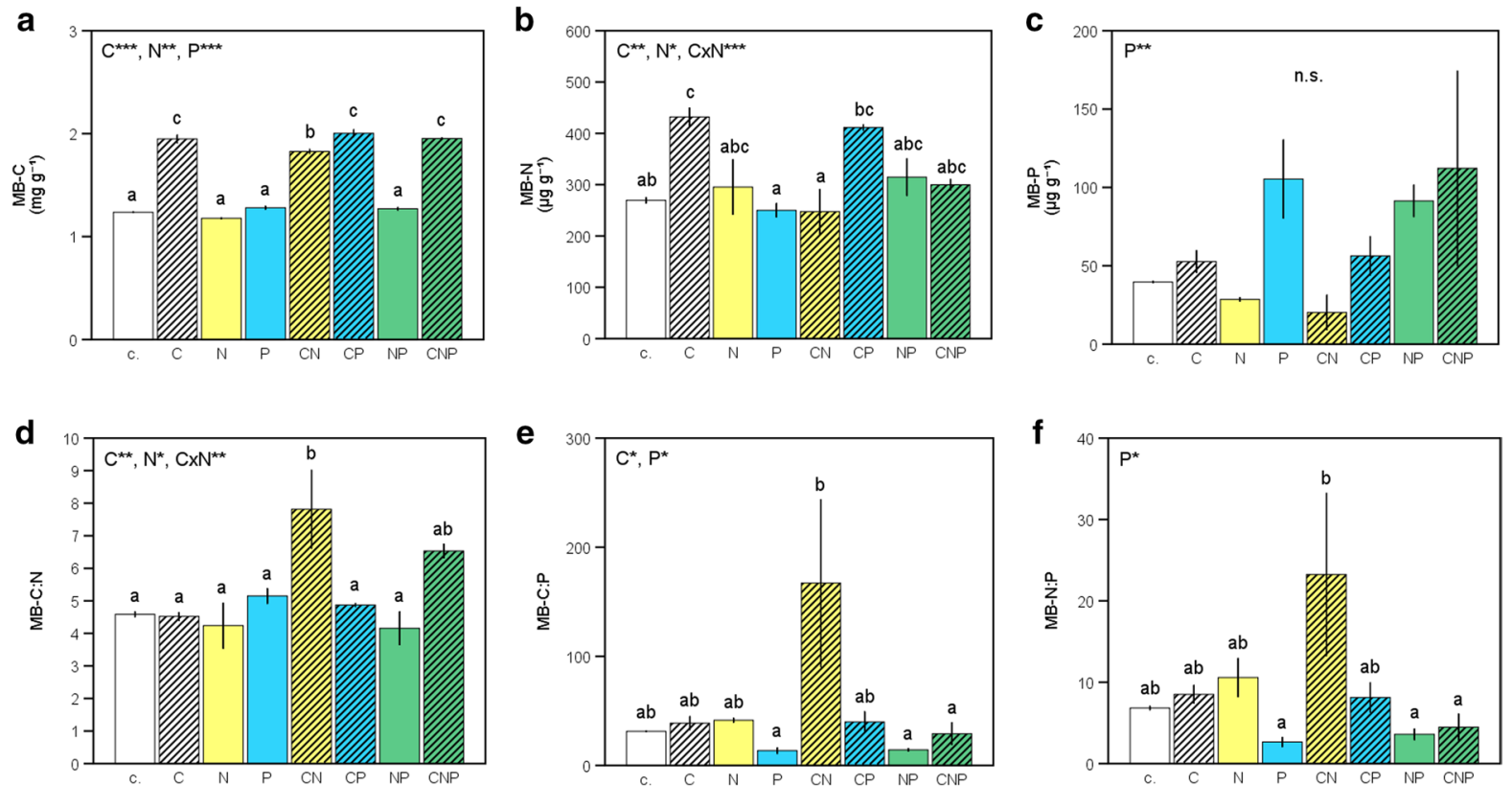

Fig. 2 Soil microbial biomass $\mathrm{C}, \mathrm{N}$ and $\mathrm{P}(\mathbf{a}-\mathbf{c}$; in $\mathrm{mg}$ and $\mu \mathrm{g}$ g dry soil $\left.{ }^{-1}\right)$ as well as microbial C:N, C:P and N:P ratios $(\mathbf{d}-\mathbf{f}$; on weight base) of the forest soil following long-term multifactorial nutrient addition (c, control). Given is the mean \pm 1 SE $(n=3)$, and different lowercase letters indicate signifi-

Bacterial and fungal growth responses to long- and short-term nutrient additions

In both the grassland and forest soil, the bacterial growth and respiration responses upon long-term multi-factorial nutrient addition suggested primary limitation by $\mathrm{C}$ and secondary limitation by $\mathrm{P}$, while fungal growth rates were mainly limited by $\mathrm{C}$ (data not shown; for more details we refer to Rosinger et al. 2019). We further tested whether the long-term nutrient additions shifted nutrient limitation of microbial growth by determining the growth-responses to repeated short-term additions of $\mathrm{C}, \mathrm{N}$ and $\mathrm{P}$. In both soils, short-term growth responses to multi-factorial nutrient additions following the long-term $\mathrm{P}$ - and NP-amendment revealed that bacteria as well as decomposer fungi remained C-limited (Supplementary Figs. 2a-f, 3a-f). Moreover, immediate growth responses to short-term multi-factorial nutrient additions following the long-term $\mathrm{CN}$ - and CNP-amendment in the forest soil revealed that bacterial growth only responded to short-term C-addition, while fungal growth did not respond at all (Supplementary cant differences between treatments at the $\mathrm{p}<0.05$ level as revealed by one-way ANOVA and post-hoc Tukey tests. Significant treatment and interaction effects as revealed by 3-way ANOVA are displayed in the upper left corner, with $* \mathrm{p}<0.05$; $* * \mathrm{p}<0.01 ; * * * \mathrm{p}<0.001$

Figure $3 \mathrm{~g}-1)$. The response of all pre-treatments to the short-term multifactorial nutrient additions can be found in the supplementary materials of Rosinger et al. (2019).

\section{Categorical PCA}

The categorical PCA of both land-use systems clearly showed a separation of all C-treatments from the ones that did not receive $\mathrm{C}$ along the first dimension, while the separation along the second dimension was driven by $\mathrm{N}$ and $\mathrm{P}$ (Fig. 3a,c). Moreover, the analysis further revealed that $(i)$ potential enzyme activities are particularly associated with the $\mathrm{CN}$-treatment in both soils, (ii) microbial growth rates, respiration and microbial biomass measures (both total PLFAs and MB-C) generally point towards all treatments that received $\mathrm{C}$, and towards the $\mathrm{C}-, \mathrm{CP}$ - and $\mathrm{CNP}-$ treatments in particular, (iii) MB-P points towards the $\mathrm{P}$ - and NP-treatments and (iv) MB-N in the grassland soil is associated with the $\mathrm{N}$ - and $\mathrm{CN}$-treatments.

As additional verification of our microbial biomass analysis, the PCA also shows a strong congruence of 
Fig. 3 a, c The first two dimensions of a categorical principal component (catPCA) analysis on a the grassland and $\mathbf{c}$ the forest soil following multifactorial nutrient additions. b, d Loading plots of the first two components from a catPCA on $\mathbf{b}$ the grassland and $\mathbf{d}$ the forest soil, showing the parameters (GLU, $\beta$-glucosidase; LAP, leucine amino-peptidase; MB-C, microbial biomass C; MB-N, microbial biomass N; MB-P, microbial biomass $\mathrm{P}$; NAG, N-acetyl$\beta$-D-glucosaminidase; PHO, acid phosphatase) that drive the segregation among the different nutrient-added treatment
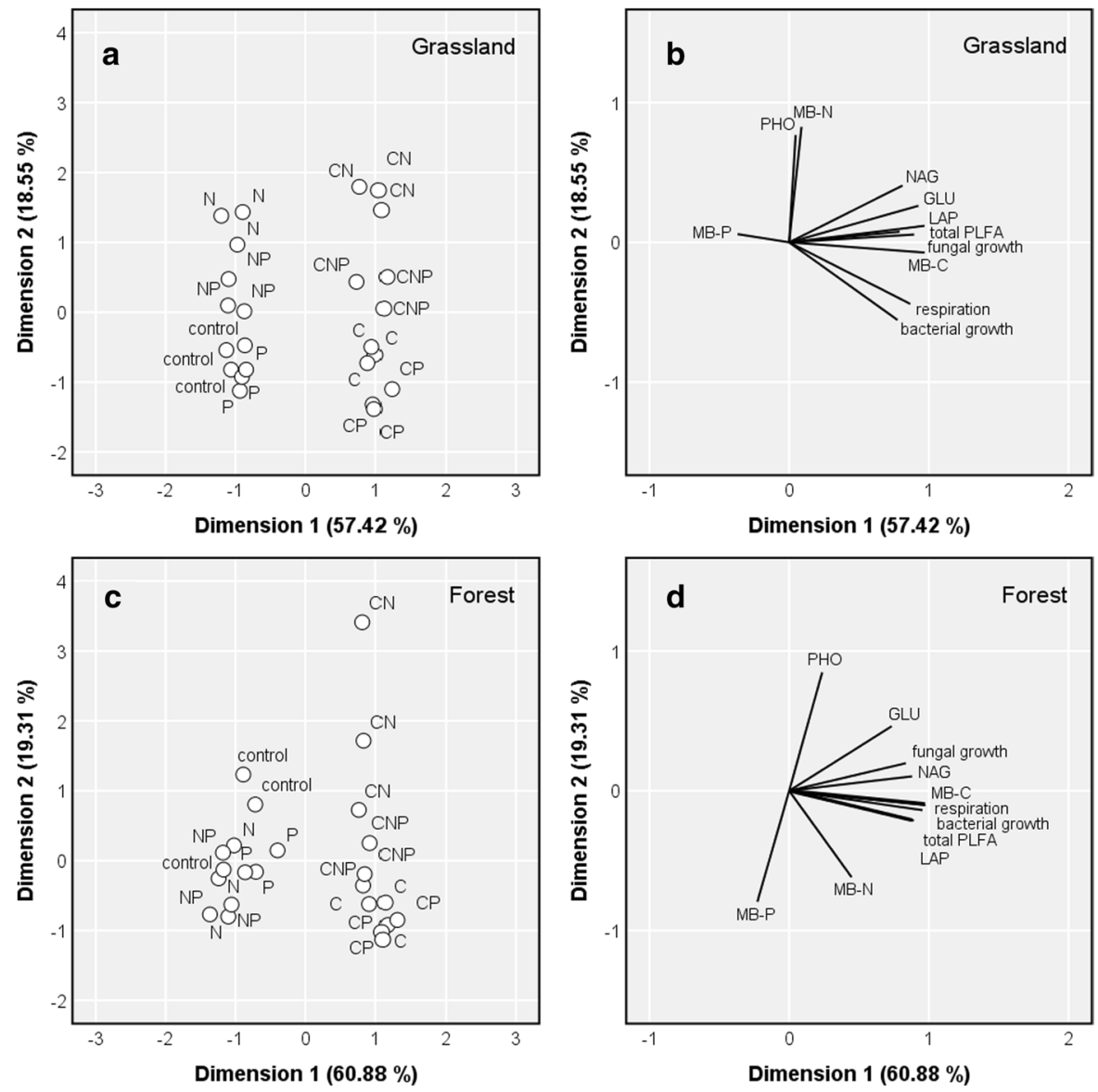

MB-C and total amounts of PLFAs, which is further confirmed by linear regression analysis and Pearson's correlation coefficient $\left(\mathrm{R}^{2}=0.9, \mathrm{p}<0.001\right)$.

\section{Discussion}

Overall, PLFA composition patterns from our study are similar to other studies from sub-Saharan subtropical soils (e.g., Lagerlöf et al. 2014; Cobb and Wilson 2018). Derived microbial C:N:P ratios deviate from the global stoichiometric ratios found in Cleveland and Liptzin (2007) or Xu et al. (2013), probably owing to the fact that data from tropical and subtropical biomes were underrepresented in the afore-mentioned studies.

In both soils, CP- and CNP-addition increased MB-C more than CN-addition (Figs. 1a, 2a), suggesting a primary limitation by $\mathrm{C}$ and secondary limitation by $\mathrm{P}$. These results are in line with bacterial and fungal growth rates, which suggested the same (Rosinger et al. 2019). This clear state of $C$ limitation of soil microbial processes in subtropical ecosystems is rather surprising and contrasts with the commonly reported notion of $\mathrm{P}$ limitation in tropical and subtropical biomes (Camenzind et al. 2018). In contrast to these observed patterns are the results on enzyme activities. Here, we found that the overall enzyme activity in the CN-treated soils was significantly higher as compared to the control, while total enzyme activities in the CP- and CNP-treated soils were indifferent from the control (Supplementary Tables 3, 4). In the grassland soil, the overall enzyme activity in the $\mathrm{CN}$-treated soil was also found to be significantly higher as compared to the CP- and CNP-treated soils, with the change mainly being driven by $\mathrm{PHO}$ activity (Supplementary Table 3). Taken together, these results suggest that microbial growth (i.e. microbial biomass increases) could have occurred at the expense of extracellular enzyme production (Flamholz et al. 
2013; Litchman et al. 2015; Ramin and Allison 2019). The conducted categorical PCA further supports this postulation, as it clearly shows that $(i)$ potential enzyme activities are particularly associated with the CN-treatment in both soils, while (ii) microbial growth rates, respiration and microbial biomass measures (both total PLFAs and microbial biomass C) are more strongly related to the C-, CP- and CNPtreatments (Fig. 3). We therefore conclude that there is a certain degree of microbial resource partitioning at the community level, with soil microbes trading off their resources between growth and the production of enzymes (Ramin and Allison 2019).

In the grassland soil, MB-N was significantly higher in all treatments that received $\mathrm{N}$ as compared to all others, resulting in significantly decreased microbial $\mathrm{C}: \mathrm{N}$ ratios in these treatments (Fig. 1b). Similarly, MB-P increased in the P-, NP- and CNPtreated grassland soils (Fig. 1c), which resulted in significantly decreased microbial C:P ratios in those treatments as compared to the control (Fig. 1e). In the forest soil, only $\mathrm{C}$-addition (and marginally $\mathrm{CP}$ addition) led to significantly higher $\mathrm{MB}-\mathrm{N}$ contents as compared to the control (Fig. 2b), while MB-P was invariant across all treatments (Fig. 2c). In contrast to the grassland soil, only the $\mathrm{CN}$-treated forest soil was subject to significant shifts in microbial $\mathrm{C}: \mathrm{N}, \mathrm{C}: \mathrm{P}$ and $\mathrm{N}: \mathrm{P}$ ratios (Fig. 2d-f). Microbial stoichiometric shifts have often been associated with changes in the microbial community, e.g. from bacterial to fungal dominance (Fanin et al. 2013; Waring et al. 2013; Mooshammer et al. 2014). For example, Fanin et al. (2013) could show that leachates with a low C:N:P ratio favoured bacterial abundance, while high $\mathrm{N}: \mathrm{P}$ and $\mathrm{C}: \mathrm{P}$ ratios favoured fungal abundance. Consequently, resource stoichiometry drives the relative abundance of certain microbial groups (e.g. fungi to bacteria; Waring et al. 2013). In our study, C-addition mainly drove shifts in microbial community composition, as all treatments that received $\mathrm{C}$ tended to favour fungi over bacteria and gramnegative over grampositive bacteria (Supplementary Figure 1); such community shifts upon straw addition (which was our C-substrate) are commonly found in literature (e.g. Henriksen and Breland 1999; Rousk and Bååth 2007; Chen et al. 2017). Overall, our data clearly indicate that microbial stoichiometry shifts do not necessarily coincide with microbial community shifts as detected by PLFA analysis. For example, the microbial C:N ratio in the grassland soil decreased with $\mathrm{CN}$ - and CNP-addition, increased with CP-addition and did not change with $\mathrm{C}$-addition as compared to the control (Fig. 1d). In the forest soil, the microbial $\mathrm{C}: \mathrm{N}$ ratio only responded to $\mathrm{CN}$-addition (Fig. 2d). PLFA data however indicate similar shifts in fungi to bacteria and grampositive to gramnegative bacteria ratios in all C-treated grassland and forest soils (Supplementary Figure 1). We therefore suggest that considerable intracellular immobilization of $\mathrm{P}$ and also of $\mathrm{N}$ for storage is partly responsible for the observed shifts in microbial stoichiometry, particularly in the nutrient-poor grassland soil (Myrold and Posavatz 2007; Scott et al. 2012; Heuck et al. 2015). This is further supported by the categorical PCA, which shows that MB-P points towards the P- and NP-treatments in both soils and MB-N in the grassland soil is associated with the $\mathrm{N}$ - and $\mathrm{CN}$-treatment (Fig. 3).

In their global analysis on soil microbial stoichiometry, Cleveland and Liptzin (2007) suggested that shifts in the microbial N:P ratio can be indicative of shifts in the nutrient limitation of soil microorganisms, due to the well-constrained nature of MB-N and -P. Translating this rationale to our data would suggest that the microbes in the P- and NP-treated grassland soil would be more $\mathrm{N}$ - as compared to P-limited, while they would be more P limited in the $\mathrm{N}$-and CN-treatments (Fig. 1f). As for the forest soil, the increased microbial $\mathrm{N}: \mathrm{P}$ ratio in the $\mathrm{CN}$-treated soil as compared to the P-, NP- and CNP-treated soils would suggest an increased $\mathrm{P}$ limitation relative to $\mathrm{N}$ limitation (Fig. 2f). However, when considering the immediate microbial growth responses to short-term additions (Supplementary Figs. 2, 3), it becomes apparent that neither the N-, P-, CN- or NP-treatments in the grassland soil nor the $\mathrm{CN}-, \mathrm{P}-, \mathrm{NP}-$ and CNP-treatments in the forest soil were able to shift the microbial growth limitation towards $\mathrm{N}$ or $\mathrm{P}$; the soil microorganisms remained C-limited. In fact, fungal growth in the P-treated grassland soil and in the $\mathrm{CN}$ - and CNP-treated forest soil was not responsive to any short-term nutrient addition (Supplementary Figure $2 \mathrm{a}, 3 \mathrm{i}, 1)$. We therefore suggest that when microbial growth is energy limited, $\mathrm{N}$ and $\mathrm{P}$ in excess can be immobilized and stored in order to provide a survival benefit during better growth conditions (Kamp et al. 2015; Bingham and Cotrufo 2016). This mechanism has been suggested to be an adaptive measure to seasonal and temporal changes in nutrient availability 
(Soong et al. 2018). Thus, only when energy limitation is (at least partly) alleviated, soil microorganisms may be able to efficiently use $\mathrm{N}$ and $\mathrm{P}$ for growth (Fanin et al. 2016). This further strengthens the notion of a rather differential microbial resource utilization and thus trade-offs at the community level, i.e. depending on the nutrient resources available, soil microbes tend to partition their available resources more towards growth, the production of extracellular enzymes or intracellular storage (Litchman et al. 2015; Ramin and Allison 2019).

Overall, strong nutrient interaction effects on microbial biomass and stoichiometry suggest a complex interplay and interdependence between resource and MB-C, $-\mathrm{N}$ and $-\mathrm{P}$ contents (Fanin et al. 2016). This was particularly the case in the grassland soil, where, for example, MB-N dynamics were influenced by combined additions of $\mathrm{C}$ and $\mathrm{P}$, and MB-P dynamics were influenced by $\mathrm{C}$ and $\mathrm{N}$ addition (Fig. 1b, c). This further underlines the complexity of predicting microbial resource use for catabolic (respiration, enzyme production) and anabolic (balanced growth) microbial processes.

To conclude, our results suggest that microorganisms in subtropical grassland and forest soils immobilize $\mathrm{N}$ and $\mathrm{P}$ for storage under conditions where $\mathrm{C}$ is the main limiting resource. These results imply a certain degree of stoichiometric plasticity of soil microbial communities, presumably via transient intracellular storage of nutrients. Moreover, changes in microbial C:N, C:P and N:P ratios were not necessarily linked to the relative dominance of fungito-bacteria or other structural differences in the microbial PLFA composition. Although we cannot entirely obviate that PLFA markers might not have captured community changes as compared to new DNA sequencing methods, there are studies showing that PLFA analyses can differentiate microbial communities as well as CLPP- or even PCR-based fingerprinting methods such as tRFLP or DGGE (Grayston et al. 2004; Ramsey et al. 2006; Chen et al. 2019b). Moreover, microbial phylogenetic groups as identified with PLFA analysis can exhibit a certain intraphylogenetic stoichiometric variability, albeit within a confined range (Strickland and Rousk 2010; Mouginot et al. 2014; Zhang and Elser 2017). For example, Mouginot et al. (2014) could show that bacteria and fungi isolated from grassland litter have average molar C:N ratios of 8.3 and 4.6, respectively, with a 95\% confidence interval of 7.3-9.5 and 4.1-4.8 for fungi and bacteria, respectively. However, the degree to which this circumstance might have influenced the observed stoichiometric shifts in our study remains unknown, and studies on the stoichiometric variability within microbial phylogenetic groups in soil, particularly upon nutrient addition, are scarce; as are studies on the effect of micro-faunal predation on microbial stoichiometric shifts (Trap et al. 2016). Clearly, more research is needed in this direction. On the contrary, the PLFA approach has the great benefit of supposedly capturing live microorganisms as compared to most molecular analysis. Shifting microbial $\mathrm{N}: \mathrm{P}$ ratios did not correspond to changes in their relative $\mathrm{N}$ to $\mathrm{P}$ limitation but rather reflected resource excess. These findings suggest that soil microorganisms can be-when subject to strong resource pulses-stoichiometrically quite flexible, which might result in rather weak homeostasis at the community scale. Thus, resource and microbial stoichiometry can to a certain degree be decoupled (Hartman and Richardson 2013). More studies covering soil microbial communities from various biomes are required to verify our findings. Moreover, studying gradients of $\mathrm{C}, \mathrm{N}$ and $\mathrm{P}$ additions could help to verify whether the observed resource partitioning between microbial growth, enzyme production and intracellular storage underlies a certain nutrient threshold. If our results from two subtropical soils can be generalised, microbial stoichiometry-just as enzymatic stoichiometry (Rosinger et al. 2019)-and responses therein upon nutrient addition do not adequately capture growthlimiting nutrients for soil microorganisms.

Acknowledgements C.R.'s research visit to LU was supported by a short-term scientific mission (STSM) grant awarded by COST Action FP1305 BioLink "Linking belowground biodiversity and ecosystem function in European forests", a network funded by the COST programme. This work was supported by a Grant (Vetenskapsrådet Grant No. 201606327) from the programme "Sustainability and resilience Tackling climate and environmental changes" jointly supported by the Swedish Research Council, the Swedish Research Council Formas, and Sida.

Funding Open access funding was provided by the University of Natural Resources and Life Sciences Vienna (BOKU).

Data availability Enquiries about data availability should be directed to the corresponding author.

\section{Declarations}


Conflict of interest The authors have not disclosed any competing interests.

Open Access This article is licensed under a Creative Commons Attribution 4.0 International License, which permits use, sharing, adaptation, distribution and reproduction in any medium or format, as long as you give appropriate credit to the original author(s) and the source, provide a link to the Creative Commons licence, and indicate if changes were made. The images or other third party material in this article are included in the article's Creative Commons licence, unless indicated otherwise in a credit line to the material. If material is not included in the article's Creative Commons licence and your intended use is not permitted by statutory regulation or exceeds the permitted use, you will need to obtain permission directly from the copyright holder. To view a copy of this licence, visit http://creativecommons.org/licenses/by/4.0/.

\section{References}

Allen AS, Schlesinger WH (2004) Nutrient limitations to soil microbial biomass and activity in loblolly pine forests. Soil Biol Biochem 36:581-589

Assefa D, Rewald B, Sandén H, Rosinger C, Abiyu A, Yitaferu B, Godbold DL (2017) Deforestation and land use strongly effect soil organic carbon and nitrogen stock in Northwest Ethiopia. CATENA 153:89-99

Bååth E, Pettersson M, Söderberg KH (2001) Adaptation of a rapid and economical microcentrifugation method to measure thymidine and leucine incorporation by soil bacteria. Soil Biol Biochem 33(11):1571-1574

Bingham AH, Cotrufo MF (2016) Organic nitrogen storage in mineral soil: Implications for policy and management. Sci Total Environ 551:116-126

Brookes PC, Landman A, Pruden G, Jenkinson DS (1985) Chloroform fumigation and the release of soil nitrogen: a rapid direct extraction method to measure microbial biomass nitrogen in soil. Soil Biol Biochem 17(6):837-842

Brookes PC, Powlson DS, Jenkinson DS (1982) Measurement of microbial biomass phosphorus in soil. Soil Biol Biochem 14(4):319-329

Buchkowski RW, Schmitz OJ, Bradford MA (2015) Microbial stoichiometry overrides biomass as a regulator of soil carbon and nitrogen cycling. Ecology 96(4):1139-1149

Buchkowski RW, Shaw AN, Sihi D, Smith GR, Keiser AD (2019) Constraining carbon and nutrient flows in soil with ecological stoichiometry. Front Ecol Evol 7:382

Camenzind T, Hättenschwiler S, Treseder KK, Lehmann A, Rillig MC (2018) Nutrient limitation of soil microbial processes in tropical forests. Ecol Monogr 88:4-21

Chen Z, Wang H, Liu X, Zhao X, Lu D, Zhou J, Li C (2017) Changes in soil microbial community and organic carbon fractions under short-term straw return in a ricewheat cropping system. Soil Tillage Res 165:121-127

Chen J, Seven J, Zilla T, Dippold MA, Blagodatskaya E, Kuzyakov Y (2019a) Microbial C: N: P stoichiometry and turnover depend on nutrients availability in soil: A
$14 \mathrm{C}, 15 \mathrm{~N}$ and $33 \mathrm{P}$ triple labelling study. Soil Biol Biochem 131:206-216

Chen H, Zhao X, Lin Q, Li G, Kong W (2019b) Using a combination of PLFA and DNA-based sequencing analyses to detect shifts in the soil microbial community composition after a simulated spring precipitation in a semi-arid grassland in China. Sci Total Environ 657:1237-1245

Cleveland CC, Liptzin D (2007) C: N: P stoichiometry in soil: is there a "Redfield ratio" for the microbial biomass? Biogeochemistry 85:235-252

Cobb AB, Wilson GW (2018) Influence of smallholder farm practices on the abundance of arbuscular mycorrhizal fungi in rural Zambia. Pedobiologia 69:11-16

Cruz-Paredes C, Wallander H, Kjøller R, Rousk J (2017) Using community trait-distributions to assign microbial responses to $\mathrm{pH}$ changes and $\mathrm{Cd}$ in forest soils treated with wood ash. Soil Biol Biochem 112:153-164

Elser JJ, Bracken ME, Cleland EE, Gruner DS, Harpole WS, Hillebrand H, Smith JE (2007) Global analysis of nitrogen and phosphorus limitation of primary producers in freshwater, marine and terrestrial ecosystems. Ecol Lett 10(12):1135-1142

Fanin N, Hättenschwiler S, Chavez Soria PF, Fromin N (2016) (A) synchronous availabilities of $\mathrm{N}$ and $\mathrm{P}$ regulate the activity and structure of the microbial decomposer community. Front Microbiol 6:1507

Fanin N, Fromin N, Buatois B, Hättenschwiler S (2013) An experimental test of the hypothesis of non-homeostatic consumer stoichiometry in a plant litter-microbe system. Ecol Lett 16:764-772

Flamholz A, Noor E, Bar-Even A, Liebermeister W, Milo R (2013) Glycolytic strategy as a tradeoff between energy yield and protein cost. Proc Natl Acad Sci USA 110:10039-10044

Frostegård A, Tunlid A, Bååth E (1993) Phospholipid fatty acid composition, biomass, and activity of microbial communities from two soil types experimentally exposed to different heavy metals. Appl Environ Microbiol 59(11):3605-3617

German DP, Weintraub MN, Grandy AS, Lauber CL, Rinkes ZL, Allison SD (2011) Optimization of hydrolytic and oxidative enzyme methods for ecosystem studies. Soil Biol Biochem 43(7):1387-1397

Grayston SJ, Campbell CD, Bardgett RD, Mawdsley JL, Clegg CD, Ritz K, Elston DJ (2004) Assessing shifts in microbial community structure across a range of grasslands of differing management intensity using CLPP, PLFA and community DNA techniques. Appl Soil Ecol 25(1):63-84

Griffiths BS, Spilles A, Bonkowski M (2012) C: N: P stoichiometry and nutrient limitation of the soil microbial biomass in a grazed grassland site under experimental P limitation or excess. Ecol Process 1(1):6

Hartman WH, Richardson CJ (2013) Differential nutrient limitation of soil microbial biomass and metabolic quotients (qCO2): is there a biological stoichiometry of soil microbes? PLoS ONE 8:e57127

Henriksen TM, Breland TA (1999) Nitrogen availability effects on carbon mineralization, fungal and bacterial growth, 
and enzyme activities during decomposition of wheat straw in soil. Soil Biol Biochem 31(8):1121-1134

Heuck C, Weig A, Spohn M (2015) Soil microbial biomass C: $\mathrm{N}$ : P stoichiometry and microbial use of organic phosphorus. Soil Biol Biochem 85:119-129

Kamp A, Høgslund S, Risgaard-Petersen N, Stief P (2015) Nitrate storage and dissimilatory nitrate reduction by eukaryotic microbes. Front Microbiol 6:1492

Lagerlöf J, Adolfsson L, Börjesson G, Ehlers K, Vinyoles GP, Sundh I (2014) Land-use intensification and agroforestry in the Kenyan highland: impacts on soil microbial community composition and functional capacity. Appl Soil Ecol 82:93-99

Litchman E, Edwards KF, Klausmeier CA (2015) Microbial resource utilization traits and trade-offs: implications for community structure, functioning, and biogeochemical impacts at present and in the future. Front Microbiol 6:254

Manzoni S, Trofymow JA, Jackson RB, Porporato A (2010) Stoichiometric controls on carbon, nitrogen, and phosphorus dynamics in decomposing litter. Ecol Monogr 80:89-106

Marx MC, Wood M, Jarvis SC (2001) A microplate fluorimetric assay for the study of enzyme diversity in soils. Soil Biol Biochem 33(12-13):1633-1640

Mooshammer M, Wanek W, Zechmeister-Boltenstern S, Richter AA (2014) Stoichiometric imbalances between terrestrial decomposer communities and their resources: mechanisms and implications of microbial adaptations to their resources. Front Microbiol 5:22

Mouginot C, Kawamura R, Matulich KL, Berlemont R, Allison SD, Amend AS, Martiny AC (2014) Elemental stoichiometry of Fungi and Bacteria strains from grassland leaf litter. Soil Biol Biochem 76:278-285

Murphy JAMES, Riley JP (1962) A modified single solution method for the determination of phosphate in natural waters. Anal Chim Acta 27:31-36

Myrold DD, Posavatz NR (2007) Potential importance of bacteria and fungi in nitrate assimilation in soil. Soil Biol Biochem 39(7):1737-1743

Ramin KI, Allison SD (2019) Bacterial tradeoffs in growth rate and extracellular enzymes. Front Microbiol 10:2956

Ramsey PW, Rillig MC, Feris KP, Holben WE, Gannon JE (2006) Choice of methods for soil microbial community analysis: PLFA maximizes power compared to CLPP and PCR-based approaches. Pedobiologia 50(3):275-280

Rosinger C, Rousk J, Sandén H (2019) Can enzymatic stoichiometry be used to determine growth-limiting nutrients for microorganisms? A critical assessment in two subtropical soils. Soil Biol Biochem 128:115-126

Rousk J, Bååth E (2007) Fungal and bacterial growth in soil with plant materials of different $\mathrm{C} / \mathrm{N}$ ratios. FEMS Microbiol Ecol 62(3):258-267

Rowland AP, Haygarth PM (1997) Determination of total dissolved phosphorus in soil solutions. J Environ Qual 26(2):410-415
Scott T, Cotner J, LaPara T (2012) Variable stoichiometry and homeostatic regulation of bacterial biomass elemental composition. Front Microbiol 3:42

Sinsabaugh RL, Follstad Shah JJ (2012) Ecoenzymatic stoichiometry and ecological theory. Annu Rev Ecol Evol Syst 43:313-343

Soong JL, Marañon-Jimenez S, Cotrufo MF, Boeckx P, Bodé S, Guenet B, Janssens IA (2018) Soil microbial CNP and respiration responses to organic matter and nutrient additions: evidence from a tropical soil incubation. Soil Biol Biochem 122:141-149

Sterner RW, Elser JJ (2002) Ecological stoichiometry: the biology of elements from molecules to the biosphere. Princeton University Press

Strickland MS, Rousk J (2010) Considering fungal: bacterial dominance in soils-methods, controls, and ecosystem implications. Soil Biol Biochem 42(9):1385-1395

Trap J, Bonkowski M, Plassard C, Villenave C, Blanchart E (2016) Ecological importance of soil bacterivores for ecosystem functions. Plant Soil 398(1-2):1-24

Turner BL, Wright SJ (2014) The response of microbial biomass and hydrolytic enzymes to a decade of nitrogen, phosphorus, and potassium addition in a lowland tropical rain forest. Biogeochemistry 117:115-130

Vance ED, Brookes PC, Jenkinson DS (1987) Microbial biomass measurements in forest soils: the use of the chloroform fumigation-incubation method in strongly acid soils. Soil Biol Biochem 19(6):697-702

Voroney RP, Brookes PC, Beyaert RP (2008) Soil microbial biomass C, N, P, and S. Soil Sampl Methods Anal 2:637-652

Waring BG, Averill C, Hawkes CV (2013) Differences in fungal and bacterial physiology alter soil carbon and nitrogen cycling: insights from meta-analysis and theoretical models. Ecol Lett 16:887-894

Witt C, Gaunt JL, Galicia CC, Ottow JC, Neue HU (2000) A rapid chloroform-fumigation extraction method for measuring soil microbial biomass carbon and nitrogen in flooded rice soils. Biol Fertil Soils 30(5-6):510-519

Xu X, Thornton PE, Post WM (2013) A global analysis of soil microbial biomass carbon, nitrogen and phosphorus in terrestrial ecosystems. Glob Ecol Biogeogr 2:737-749

Zhang J, Elser JJ (2017) Carbon:nitrogen:phosphorus stoichiometry in fungi: a meta-analysis. Front Microbiol 8:1281

Publisher's Note Springer Nature remains neutral with regard to jurisdictional claims in published maps and institutional affiliations. 